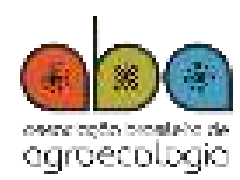

ISSN: $1980-9735$

DOI: $10.33240 /$ rba.v15i3.23260

Vol. $15 \mid \mathrm{N}^{0} .3$ | p. $141-142 \mid 2020$

RESUMO DE TESE

\title{
A HOMEOPATIA COMO INDUTORA DE RESISTÊNCIA DO FEIJOEIRO À HERBIVORIA DE INSETOS EM SISTEMAS AGROECOLÓGICOS
}

\author{
Homeopathy as resistance inducer in common bean against insect herbivory in
}

agroecological systems

${ }^{1}$ Doutora pelo programa de Pósgraduação Stricto Sensu Agronomia. Universidade Passo Fundo, Passo Fundo, 2019 tarita.deboni@yahoo.com.br

Orientadora: Profa Dra. Cláudia Petry

Ano de defesa: 2019.

Recebido em: 04/06/2020

Aceito em: $08 / 06 / 2020$

Correspondência para: tarita.deboni@yahoo.com.br
Tarita Cira Deboni

\section{RESUMO}

A homeopatia vem apresentando resultados no metabolismo das plantas, promovendo suas defesas naturais, que podem ser mensuradas através de análises bioquímicas e fisiológicas. Entretanto, ainda pouco se sabe a respeito da atuação dos preparados homeopáticos no sistema de defesa das plantas à herbivoria por insetos, e se estes podem atuar como indutores de resistência agindo na auto-regulação das plantas. O objetivo deste trabalho foi avaliar se os preparados homeopáticos atuam na indução de resistência em feijoeiro contra a herbivoria de insetos em sistemas de transição agroecológicos. O primeiro experimento foi de triagem, em que foram testados os seguintes preparados homeopáticos: Arsenicum album, Staphisagria, Silicea terra e Sulphur, nas potências $6 \mathrm{CH}, 12 \mathrm{CH}$ e $18 \mathrm{CH}$, comparados às testemunhas. Já para o segundo experimento foram selecionados apenas: Arsenicum album $6 \mathrm{CH}$, silicea terra $6 \mathrm{CH}$, Staphisagria $12 \mathrm{CH}$ e Sulphur $6 \mathrm{CH}$. Ambos experimentos conduzidos em estufa, em delineamento inteiramente casualizado, com aplicação dos tratamentos a $1 \%$ em água destilada e comparados às testemunhas. No segundo experimento o feijoeiro foi cultivado em duas gerações subsequentes: a primeira foi a parental e a segunda a progênie e houve estresse causado por herbivoria da lagarta Helicoverpa armigera (Lepidoptera: Noctuidae). Determinou-se a concentração de proteínas e a atividade das enzimas guaiacol peroxidase (POD) e ascorbato peroxidase (APX) em folhas e raízes do feijoeiro. As diferenças entre os tratamentos e as testemunhas de ambos experimentos foram estimadas por análises de tamanho de efeito Delta de Glass. O terceiro experimento foi conduzido a campo, na safra 2019, em delineamento fatorial duplo com esquema de parcelas subdivididas. Na parcela foram dispostos os tratamentos Arsenicum album $6 \mathrm{CH}$, Silicea terra $6 \mathrm{CH}$, e a testemunha com água destilada, e na subparcela a presença ou ausência de tela de proteção. As variáveis analisadas foram concentração de proteína, atividade de fenilalanina amônia-liase (FAL), peroxidação de lipídios (MDA), trocas gasosas, teor de clorofila, componentes do rendimento e, proteína e nitrogênio total nos grãos. Em laboratório foram conduzidos três experimentos com a lagarta $H$. armige$r a$, sendo um destes com livre escolha, avaliando o efeito de antixenose e outro sem chance de escolha, avaliando o efeito de antibiose. Nestes últimos os dados foram submetidos a análise de variância e as médias comparadas pelo teste de Tukey $(p<0,05)$. Os preparados homeopáticos Arsenicum album, Silicea terra, Staphisagria e Sulphur causaram alterações na concentração de proteína e atividade de peroxidases, APX e POD, em plantas de feijoeiro cultivadas na estufa. Estas alterações demostraram efeito transgeracional quando as plantas foram expostas aos danos por herbivoria causados pela lagarta $H$. armigera, indicando potencial indutor de resistência dessas homeopatias. O feijoeiro tratado com preparados homeopáticos Arsenicum album $6 \mathrm{CH}$ e Silicea terra $6 \mathrm{CH}$ provocou resposta do tipo antixenose e antibiose nas lagartas de $H$. armigera. A homeopatia demonstra que pode induzir o sistema de defesa das plantas facilitando os processos de transição agroecológica.

Palavras-Chave: Preparados Homeopáticos. Indução de Resistência. Transição Agroecológica. Phaseolus vulgaris. Helicoverpa armigera. 


\section{ABSTRACT}

Homeopathy has been showing results in plant metabolism, promoting its natural defenses, which can be measured through biochemical and physiological analyses. However, little is known about the role of homeopathic preparations in the plant defense system against insect herbivory, and whether they can act as resistance inducers promoting plant self-regulation. The objective of this study was to evaluate if homeopathic preparations act on resistance induction in common bean against insect herbivory in agroecological transition systems. The first experiment was a screening, in which the following homeopathic preparations were tested: Arsenicum album, Staphisagria, Silicea terra and Sulphur, in the potencies $6 \mathrm{CH}, 12 \mathrm{CH}$ and $18 \mathrm{CH}$, compared to the controls. For the second experiment, only Arsenicum album $6 \mathrm{CH}$, silicea terra $6 \mathrm{CH}$, Staphisagria $12 \mathrm{CH}$ and Sulphur $6 \mathrm{CH}$ were selected. Both experiments were conducted in a completely randomized design, with the application of the treatments at $1 \%$ in distilled water and compared to the controls. In the second experiment the common bean was grown in two subsequent generations: the first was the parental one and the second was the progeny and, in this case, there was a stress caused by the herbivory of the Helicoverpa armigera (Lepidoptera: Noctuidae) caterpillar. Protein concentration and activity of guaiacol peroxidase (POD) and ascorbate peroxidase (APX) enzymes in bean leaves and roots were determined. Differences among treatments and controls from both experiments were estimated by Glass's Delta effect size analysis. The third experiment was conducted in the field, in the $2019 \mathrm{crop}$, in a double factorial design with split plot scheme. Arsenicum album $6 \mathrm{CH}$, Silicea terra $6 \mathrm{CH}$ and the control with distilled water were arranged in the plot and, in the subplot, it was allocated the presence or absence of a protective screen. The variables analyzed were protein concentration, phenylalanine ammonia lyase activity (FAL), lipid peroxidation (MDA), gas exchange, chlorophyll content, yield components, and protein and total nitrogen in the grains. In the laboratory, three trials were performed with the $H$. armigera caterpillar, one of them with free choice, evaluating the antixenosis effect and the other without chance of choice, assessing the antibiosis effect. Data from these last tests were subjected to analysis of variance and the means were compared by Tukey test $(p<0.05)$. The homeopathic preparations of Arsenicum album, Silicea terra, Staphisagria and Sulphur caused changes in protein concentration and in the activity of peroxidases, APX and POD on bean plants cultivated in greenhouse. These changes showed transgenerational effect when the plants were exposed to herbivory damage caused by $\mathrm{H}$. armigera caterpillar, indicating the potential resistance induction of these homeopathies. The common bean treated with homeopathic preparations of Arsenicum album $6 \mathrm{CH}$ and Silicea terra $6 \mathrm{CH}$ caused antixenosis and antibiosis responses in $H$. armigera caterpillars. These results demonstrate that homeopathy can induce plant defense systems, facilitating the agroecological transition processes.

Keywords: Homeopathic Preparations. Resistance Induction. Agroecological Transition. Phaseolus vulgaris. Helicoverpa armigera. 